EL LECTOR

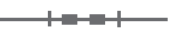




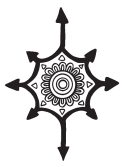

LLILAS Translations from Latin America Series 


\section{EL LECTOR}

A History of the Cigar Factory Reader

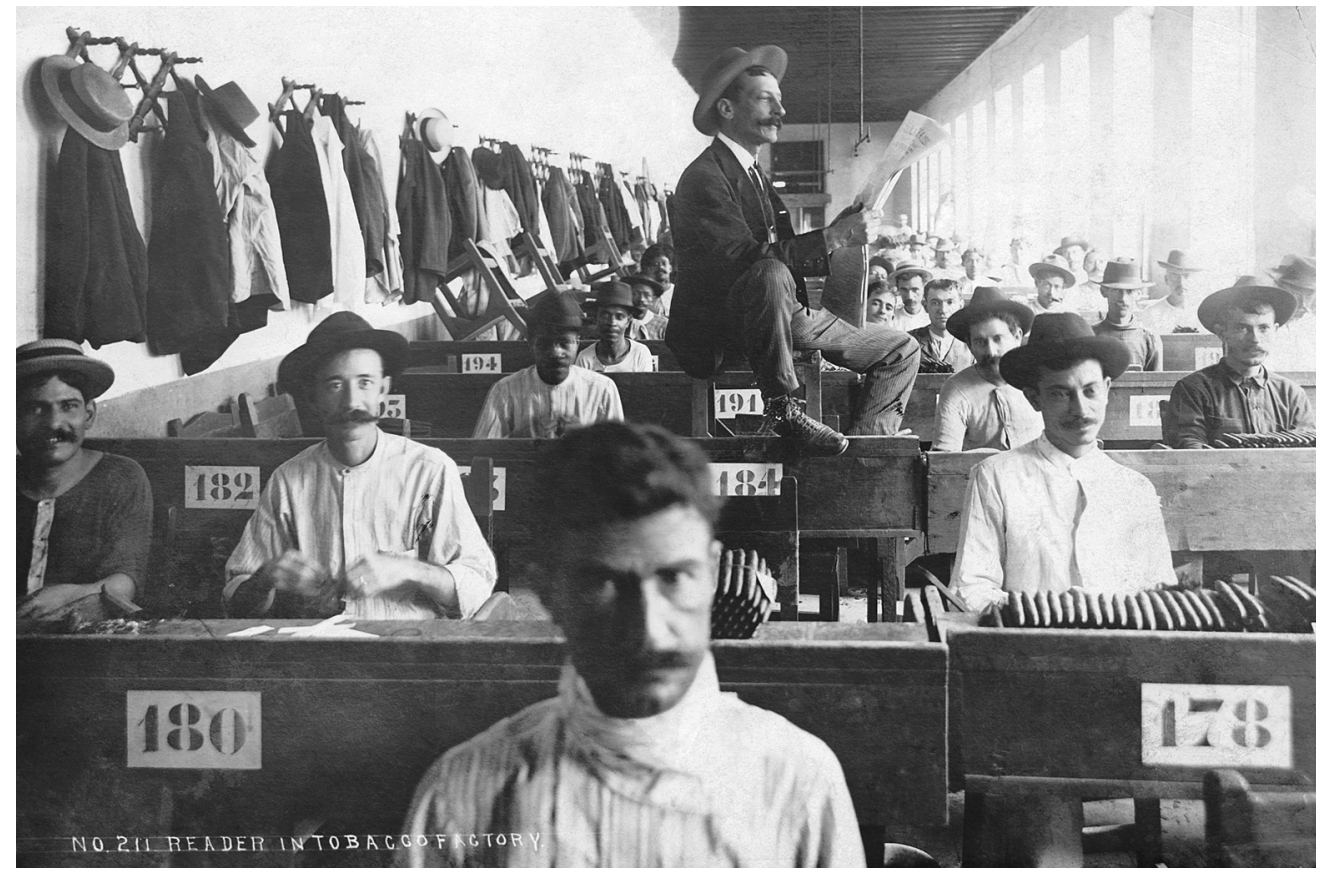

ARACELI TINAJERO

Translated by Judith E. Grasberg

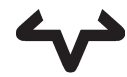

UNIVERSITY OF TEXAS PRESS

TERESA LOZANO LONG INSTITUTE OF LATIN AMERICAN STUDIES 
The author gratefully acknowledges the contribution of Patti Firth in providing the translations of José Martí and the poetry that appears in the book.

Originally published in 2007 as El lector de tabaquería: Historia de una tradición Cubana. Madrid: Editorial Verbum. Copyright (c) 2007 by Araceli Tinajero.

FRONTISPIECE: A hired reader reads to cigar makers hard at work in a Cuban cigar factory ca. 1900-1910. Copyright (C) Hulton-Deutsch Collection/ CORBIS.

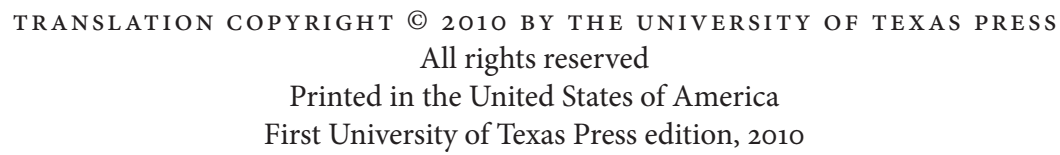

Requests for permission to reproduce material from this work should be sent to:

$$
\begin{gathered}
\text { Permissions } \\
\text { University of Texas Press } \\
\text { P.O. Box } 7819 \\
\text { Austin, TX } 78713-7819 \\
\text { www.utexas.edu/utpress/about/bpermission.html }
\end{gathered}
$$

@ The paper used in this book meets the minimum requirements of ANSI/NISO Z39.48-1992 (R1997) (Permanence of Paper).

LIBRARY OF CONGRESS CATALOGING-IN-PUBLICATION DATA

Tinajero, Araceli, 1962-

[Lector de tabaquería. English]

El lector : a history of the cigar factory reader / by Araceli Tinajero ; translated by Judith E. Grasberg. — 1st ed.

p. $\mathrm{cm}$.

Includes bibliographical references and index. ISBN 978-0-292-72175-3 (alk. paper)

1. Oral reading. 2. Tobacco industry-Cuba-History. 3. Tobacco workersCuba-History. 4. Tobacco industry-Puerto Rico-History. 5. Tobacco workers -Puerto Rico-History. 6. Tobacco industry-United States-History. 7. Tobacco workers-United States-History. I. Title.

HD9144.C9T56132009

$306.4^{\prime} 88-\mathrm{dc} 22$

2009045169 


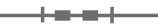

To Josefina Tinajero y López (1927-2009),

for her endless affection and compassion,

and who read aloud to me from the time I was born 
THIS PAGE INTENTIONALLY LEFT BLANK 